DOI 10.1590/S0104-64972015002308

\title{
Length-weight relationship and condition factor of Macrobrachium amazonicum (Heller, 1862) (Decapoda, Palaemonidae) from a reservoir in Bahia, Brazil
}

Sérgio Schwarz da Rocha, Ricardo Loreno Souza da Silva, Jayane de Lima Santos and Guilherme de Oliveira

(SSR, RLSS, JLS) Laboratório de Bioecologia de Crustáceos, Setor de Ciências Biológicas, Centro de Ciências Agrárias, Ambientais e Biológicas, Universidade Federal do Recôncavo da Bahia. Rua Rui Barbosa, 710. 44380-000 Cruz das Almas, Bahia, Brazil. E-mail: (SSR) ssrocha@ufrb.edu.br (GO) Laboratório de Biogeografia da Conservação, Setor de Ciências Biológicas, Centro de Ciências Agrárias, Ambientais e Biológicas, Universidade Federal do Recôncavo da Bahia. Rua Rui Barbosa, 710. 44380-000 Cruz das Almas, Bahia, Brazil.

\begin{abstract}
Macrobrachium amazonicum (Heller, 1862) is a freshwater prawn occurring in rivers and reservoirs of Central and South America. Given its broad geographical distribution, the species shows great intraspecific morphological, reproductive, physiological and ecological plasticity. Furthermore, it also stands out for its economic importance, especially in the states of North (Pará and Amapá) and Northeast Brazil. Despite the wide geographic distribution and economic importance of M. amazonicum, the biology of this species is poorly known, particularly in Northeast Brazil. We analyzed the length-weight relationships and condition factor of males and females of M. amazonicum. Specimens were collected monthly from September 2008 to August 2009 at the Pedra do Cavalo Reservoir, city of Cabaceiras do Paraguaçu, State of Bahia. All specimens were sexed, measured and weighted. After that, lengthweight relationships and the allometric $(\mathrm{K})$ and relative $\left(\mathrm{K}_{\mathrm{r}}\right)$ condition factors were calculated. Altogether 2,974 specimens were analyzed, 334 of which were males (11\%) and 2,640 were females (89\%). Females were larger and heavier than males. Males and females showed isometric and negative allometric growth, respectively. Monthly variations in the condition factor were similar for both sexes, and correlated strongly with rainfall regime and temperature in the region. Such variations are not correlated with the reproductive cycle of the species, but are probably correlated with food availability and somatic growth.
\end{abstract}

Key words: allometry, Pedra do Cavalo, prawn, relative growth.

\section{INTRODUCTION}

Length-weight relationships are typically represented by the function $\mathrm{W}=\mathrm{aL}^{\mathrm{b}}$ (where: $\mathrm{W}$ = weight, $\mathrm{L}=$ length, $\mathrm{a}=$ regression intercept, $\mathrm{b}=$ slope) (Pinheiro and Taddei, 2005; Pinheiro and Fiscarelli, 2009). This biometric relationship has often been used for morphometric comparisons between the sexes or among different populations. In fishery biology, it has also been used to estimate the weight of individuals when only their size is known, to indicate the type of weight gain, to draw biomass and economic curves, and to manage the operation and management of commercial species (Le Cren, 1951; Santos, 1978; Bolger and Connolly, 1989; Barbieri et al., 2000; Gomiero and Braga, 2003; Pinheiro and Fiscarelli, 2009).

From the analysis of the weight as a function of size, it is also possible to calculate the condition factor $(\mathrm{K})$, which is widely used in fishery biology because it is believed to indicate animal "well-being" 
and degree of adjustment to the environment (Vazzoler, 1981; Braga, 1986). Thus, variations in K over time may reflect fat accumulation, energy investment in growth and/or expenditure of energy reserves in cyclical activities such as reproduction and growth (Branco et al., 1992; Branco and Lunardon-Branco, 1993; Gomiero and Braga, 2005; Lima-Junior and Goitein, 2006).

The condition factor and weight-length ratio have been investigated for several Brazilian species of fishes (Isaac-Nahum and Vazzoler, 1983; Gomiero and Braga, 2003, 2006; Lima-Junior and Goitein, 2006; Azevedo and Castro, 2008; Gomiero et al., 2008; Tavares-Dias et al., 2008; Sá-Oliveira et al., 2011), crabs (Branco and Thives, 1991; Branco et al., 1992; Branco and Lunardon-Branco, 1993; Pinheiro and Taddei, 2005; Pinheiro and Fiscarelli, 2009; Araújo and Lira, 2012; Araújo et al., 2012; Lira et al., 2012; Patil and Patil, 2012) and prawns (Moraes-Riodades and Valenti, 2002; Albertoni et al., 2003; Flexa et al., 2005; Silva et al., 2007; Freire et al., 2012).

Among the species of Brazilian freshwater prawns, Macrobrachium amazonicum (Heller, 1862) (Palaemonidae) stands out for its high potential for commercial exploitation (Coelho and Ramos-Porto, 1985; Sampaio et al., 2007; Moraes-Valenti and Valenti, 2007; Maciel and Valenti, 2009; Pantaleão et al., 2014). A number of authors have highlighted its economic importance in the states of Northeast Brazil, and states of Pará and Amapá, North Brazil, registering increasing exploitation of natural stocks in the last decade (Silva et al., 2002; Maciel and Valenti, 2009; Lucena-Frédou et al., 2010).

Macrobrachium amazonium has wide distribution, including several river basins, such as the Orinoco, Amazon, São Francisco, AraguaiaTocantins, Paraná, Paraguay, and rivers in the Northeastern, Eastern and Northern coasts of Brazil (Melo, 2003; Maciel and Valenti, 2009). In addition, Vergamini et al. (2011) recorded the species in Panama, Costa Rica and Nicaragua, thus expanding its known distribution to Central America. More recently, Santos et al. (2013) based on morphological, ecological, reproductive, developmental, behavioral, and physiological traits concluded that the Pantanal population of
M. amazonicum constitutes a new species named Macrobrachium pantanalense Santos, Hayd and Anger, 2013. Nevertheless, Vergamini et al. (2011) compared inland (including Pantanal region) and coastal populations of $M$. amazonicum from Brazil, using molecular data (16S and COI mtDNA) and concluded that genetic divergence rates among populations showed variability at the intraspecific level, which supports their characterization as a single species.

Due to the wide geographical distribution of $M$. amazonicum, different populations inhabit environments with different characteristics, signaling that the species has wide morphological, reproductive, physiological and ecological plasticity (Maciel and Valenti, 2009; Pileggi and Mantelatto, 2010; Vergamini et al., 2011). This intraspecific variation reinforces the need for comparative studies on the biology of different populations, many of which are genetically isolated (Vergamini et al., 2011). According to Pantaleão et al. (2012) the knowledge of the life history of $M$. amazonicum is focused on populations from estuarine regions and complementary studies focusing on other environments are needed.

Despite the great economic importance of $M$. amazonicum, there is little information on the biology of this species particularly in northeastern Brazil. As far as we know, only Bragagnoli and Grotta (1995) have studied aspects of the reproductive biology of a population inhabiting a dam in the state of Paraíba and Silva et al. (2004), Santos et al. (2006) and Sampaio et al. (2007) studied various aspects of the life history (reproductive cycle, ovarian maturation stages, size of first maturation, fecundity, fertility, population structure, relative growth) of a population from Jaguaribe River, state of Ceará. Thus, the objective of this study was to investigate the length-weight relationship and condition factor for males and females of a population of $M$. amazonicum that occurs in the Pedra do Cavalo Reservoir, state of Bahia, where it is economically exploited by riverside communities.

\section{Material and Methods}

The Pedra do Cavalo Dam and its Reservoir (drainage area: 53,650 $\mathrm{km}^{2}$ ) was built in 1986 
to ensure the water supply for the metropolitan region of Salvador and other cities, and to control flooding of the Paraguaçu River. In 2005, the dam also began to generate power after the implantation of the Pedra do Cavalo Hydroeletric Power Plant (Genz, 2006). In order to protect the watershed and ensure the water quality of the Reservoir, an environmental protection area (APA) Lago de Pedra do Cavalo (total area: 30,146 ha) was created in 1997. Despite the existence of such protected area, there are a number of environmental problems in the region, such as: dumping of domestic sewage and garbage into the lake; human occupation of permanent preservation areas (the lake shores and riparian forest of tributaries); deforestation; and agricultural practices in the flood quota of the lake.

The sampling site (12³0'13.2”S 3906'33.7”W) was located at Geolândia District, municipality of Cabaceiras do Paraguaçu (Fig. 1), within the limits of the APA, approximately $20 \mathrm{~km}$ from the dam (Pedra do Cavalo Hydroeletric Power Plant). The area showed characteristics of a lentic environment, with sandy bottom and large quantity of partially submerged vegetation at the lake margin, and no riparian forest. Water temperatures at the sampling site were measured with a multiparameter meter (Hanna HI 9828) and rainfall data (calculated from a set of data of 30 years observation) were obtained from the website Clima Tempo (http:// www.climatempo.com.br/climatologia/5295/ cabaceirasdoparaguacu-ba) and are compiled in Table 1.

Specimens were collected monthly, from September 2008 to August 2009 with ten traps made from PET bottles and baited with boiled cassava. Traps were set late in the evening and inspected for captured individuals in the following morning. Our fishing gear and capture technique was the same as used by the riverside community. Voucher specimens were deposited at the Museum of Zoology, Federal University of Bahia, Brazil (MZUFBA, accession number 2724).

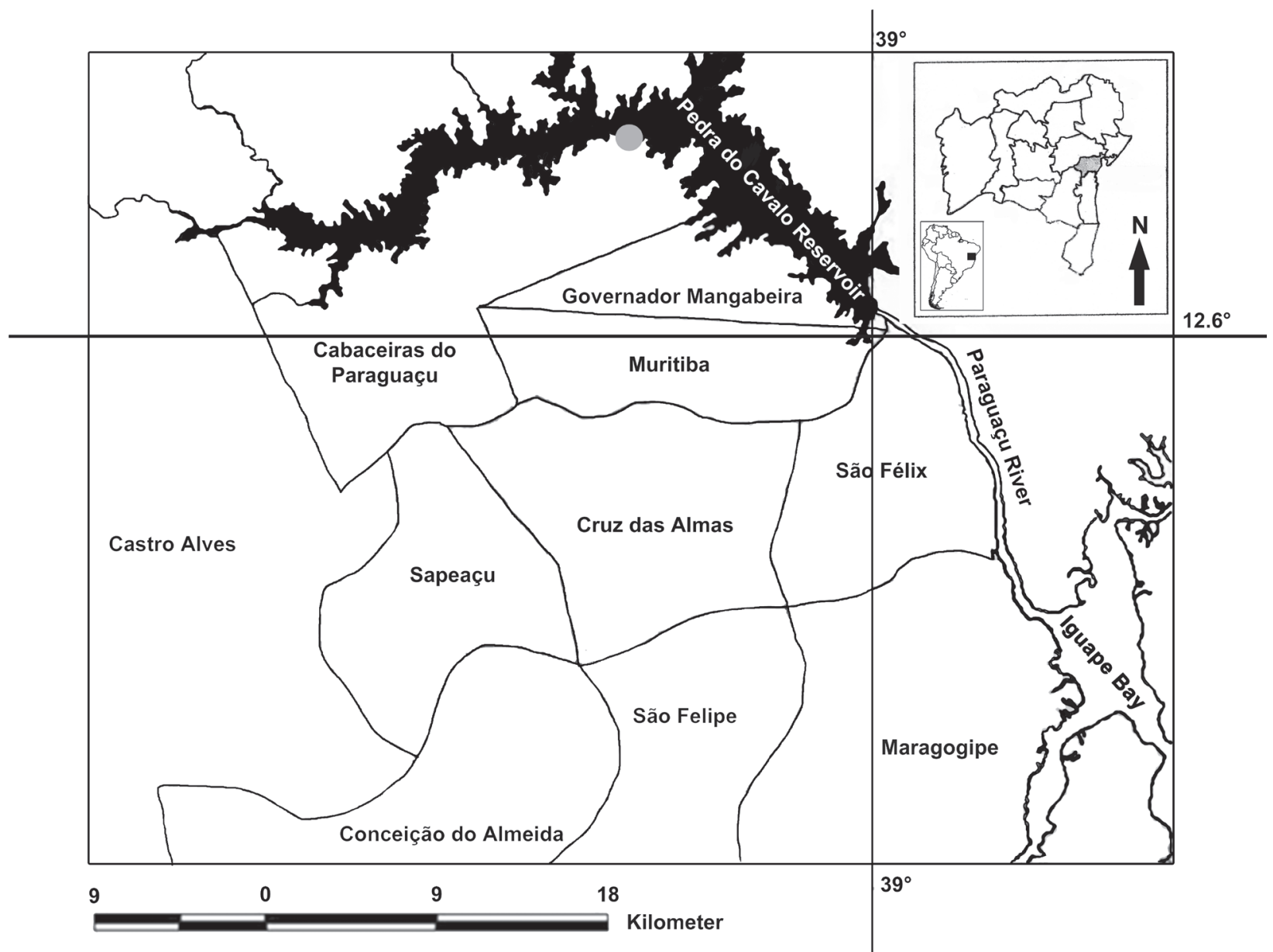

Figure 1. Map of Recôncavo da Bahia region, Brazil. Black area, Pedra do Cavalo Reservoir; gray spot, sampling site (12³0'13.2”'S 3906’33.7”W) at Geolândia District. 
Table 1. Water temperature and monthly rainfall from the municipality of Cabaceiras Paraguaçu, state of Bahia, Brazil.

\begin{tabular}{ccc}
\hline Month & $\begin{array}{c}\text { Water temperature } \\
\left({ }^{\circ} \mathrm{C}\right)\end{array}$ & $\begin{array}{c}\text { Mean Precipitation } \\
(\mathrm{mm})\end{array}$ \\
\hline January & 31.1 & 75 \\
February & 31.0 & 82 \\
March & 30.3 & 93 \\
April & 28.3 & 111 \\
May & 27.3 & 102 \\
June & 26.6 & 102 \\
July & 26.0 & 88 \\
August & 26.3 & 69 \\
September & 27.2 & 60 \\
October & 27.0 & 50 \\
November & 29.0 & 74 \\
December & 29.3 & 85 \\
\hline
\end{tabular}

After capture, prawns were fixed in $70 \%$ ethanol and stored in properly labeled plastic bottles. Determination of species was based on Melo (2003). Specimens were sexed according to the presence (male) or absence (female) of the appendix masculina on the second pair of pleopods. As performed by Pantaleão et al. (2012, 2014), the presence of different male morphotypes was assessed visually, according to the four groups of males identified by Moraes-Riodades and Valenti (2004) and confirmed by principal component analysis (PCA) using the PAST (Paleontological Statistics Software, version 2.14) computer program (Hammer et al., 2001).

Total body length ( $\mathrm{TL}=$ from the tip of the rostrum to the end of the telson) was measured to the nearest $0.01 \mathrm{~mm}$ with a digital caliper. Finally, to obtain the wet weight (W), a precision scale (range: $0.01 \mathrm{~g}$ ) was used after specimens were placed on absorbent paper to drain the excess fluid over their body. All specimens that had lesions or missing appendages were excluded from analyzes. The total length and weight of males and females were compared using the nonparametric MannWhitney test, since the data pertaining to males (length: $\mathrm{W}=0.86, \mathrm{p}<0.001$; weight: $\mathrm{W}=0.60$, $\mathrm{p}$ $<0.001$ ) and females (length: $\mathrm{W}=0.82 ; \mathrm{p}<0.001$; weight: $\mathrm{W}=0.56, \mathrm{p}<0.001)$ were not normally distributed (Zar, 1996).

Data from all measurements taken were converted to the linear form by means of natural logarithm transformation. Log transformed values of total body length $(\ln T L)$ and weight $(\ln W)$ were used as the independent and dependent variables, respectively. The entire data set, with males and females separated, was subjected to successive linear regression analysis (using Microsoft Office EXCEL 2003), and data with corresponding absolute values of the standardized residuals higher than 2.57 ( $\mathrm{p}<$ 0.01 ) were considered outliers and excluded from the analysis. This procedure was repeated until all outliers were detected and excluded. Student's t test was applied to compare the parameters of allometric equations of males and females, in order to verify the possibility of sexual dimorphism (Zar, 1996).

The state of allometry was determined by testing the coefficient of allometry " $b$ " of each linear equation (males and females) obtained from regression analysis, using Student's t test (Zar, 1996). Whenever the " $b$ " value was statistically equal to $3\left(\mathrm{H}_{0}\right)$, growth was considered isometric; when " $b$ " was different from $3\left(\mathrm{H}^{\prime}\right)$ growth was considered positively $(\mathrm{b}>3)$ or negatively $(\mathrm{b}<3)$ allometric (Hartnoll, 1982).

To calculate the allometric condition factor, the non logarithmized data of males and females were analyzed separately. The individual value of the condition factor of each specimen was calculated from the equation $\mathrm{a}=\mathrm{W} /(\mathrm{TL})^{\mathrm{b}}$, where "W" is the specimen wet weight, "TL" is the specimen total length, " $a$ " is the degree of fattening (condition factor), and " $b$ " is a constant related to the type of growth obtained from the W/TL relationship for each sex. The monthly mean values of the condition factor were calculated for each sex, and were used to perform analyzes (Hartnoll, 1982; Pinheiro and Taddei, 2005; Pinheiro and Fiscarelli, 2009).

The relationships between the monthly condition factor and monthly climate conditions (temperature and precipitation), and frequency of ovigerous females were tested using Pearson correlation coefficient (Zar, 1996).

Finally, the monthly values of the relative condition factor $\left(\mathrm{K}_{\mathrm{r}}\right)$ were determined for each sex separately. According to Le Cren (1951), $\mathrm{K}_{\mathrm{r}}=\mathrm{W}_{\mathrm{obs}}$ l $\mathrm{W}_{\text {exp }}$, where $\mathrm{W}_{\text {obs }}$ = weight observed in individuals during weighing; $W_{\text {exp }}=$ expected weight, calculated from the equations of relative growth (W/TL), obtained from the data of males and females. Mean values of $\mathrm{K}_{\mathrm{r}}$ obtained for each month were compared with the expected value of $\mathrm{K}_{\mathrm{r}}(=1)$ using the PAST 
(Paleontological Statistics Software, version 2.14) computer program (Hammer et al., 2001).

\section{Results}

Of the total of 2,974 specimens of Macrobrachium amazonicum sampled, 334 (11\%) were males and $2,640(89 \%)$ were females. A small percentage (n $=56 ; 2.12 \%)$ of ovigerous females was recorded (maximum of $10.8 \%$ in September 2008) throughout the sampling period, with the exception of November 2008 and July and August 2009.
The PCA analysis (Tab. 2; Fig. 2) indicated no separation of distinct male groups. Therefore, only the translucent claw male group (sensu MoraesRiodades and Valenti, 2004) was present in the studied population.

Total length ranged from 28.39 to $76.97 \mathrm{~mm}$ $($ median \pm S.D. $=38.80 \pm 6.12 \mathrm{~mm} ;$ mean $=$ $39.76 \mathrm{~mm}$ ) in males and from 23.32 to 97.44 $\mathrm{mm}($ median \pm S.D. $=39.42 \pm 9.03 \mathrm{~mm}$; mean $=$ $41.51 \mathrm{~mm}$ ) in females. The weight of males ranged from 0.22 to $3.5 \mathrm{~g}$ (median \pm S.D. $=0.43 \pm 0.34$

Table 2. Macrobrachium amazonicum. Factor coordinates based on the correlations (Cor.) and contributions (Con.) of the morphometric variables resulted from PCA analysis. (CC) carapace length, (LPL) left propodus length, (LPW) left propodus width, (RPL) right propodus length, (RPW) right propodus width, (AW) abdominal width.

\begin{tabular}{cccccccccccccc}
\hline Variable & \multicolumn{2}{c}{ PC1 } & \multicolumn{2}{c}{ PC2 } & \multicolumn{2}{c}{ PC3 } & \multicolumn{2}{c}{ PC4 } & \multicolumn{2}{c}{ PC5 } & \multicolumn{2}{c}{ PC6 } \\
\hline (log) & Cor. & Con. & Cor. & Con. & Cor. & Con. & Cor. & Con. & Cor. & Con. & Cor. & Con. \\
CC & 0.433 & 0.123 & 0.553 & 0.297 & -0.107 & 0.049 & 0.090 & 0.083 & 0.588 & 0.934 & -0.048 & -0.119 \\
LPL & 0.575 & 0.324 & 0.494 & 0.482 & -0.095 & -0.108 & -0.255 & -0.425 & -0.082 & -0.237 & -0.151 & -0.644 \\
LPW & 0.796 & 0.626 & -0.139 & -0.223 & -0.340 & -0.697 & 0.090 & 0.249 & 0.003 & 0.012 & 0.033 & 0.096 \\
RPL & 0.587 & 0.295 & 0.434 & 0.382 & -0.110 & 0.078 & -0.309 & -0.464 & -0.011 & -0.030 & 0.239 & 0.738 \\
RPW & 0.783 & 0.611 & -0.261 & -0.419 & -0.047 & 0.662 & -0.006 & -0.017 & 0.001 & 0.002 & -0.001 & -0.107 \\
AW & 0.404 & 0.161 & 0.675 & 0.556 & -0.064 & 0.233 & 0.519 & 0.731 & -0.109 & -0.266 & 0.032 & 0.073 \\
\hline
\end{tabular}

$\mathrm{g}$; mean $=0.50 \mathrm{~g})$ and that of females from 0.09 to $7.19 \mathrm{~g}$ (median \pm S.D. $=0.53 \pm 0.66 \mathrm{~g}$; mean $=0.71 \mathrm{~g})$. Adult females attained larger size $(\mathrm{U}=$ 405100, $\mathrm{p}=0.015)$ and weight $(\mathrm{U}=311960, \mathrm{p}<$ $0.001)$ than males indicating that there is sexual dimorphism in the studied population.

After adjustment of the growth rate in weight (W/TL) according to the power function ( $\mathrm{y}=$ $\mathrm{ax}^{\mathrm{b}}$ ) the following equations were obtained: W $=0.000009 T L^{2.95}\left(\mathrm{R}^{2}=0.86\right)$ for males and $\mathrm{W}$ $=0.000014 T L^{2.87}\left(\mathrm{R}^{2}=0.92\right)$ for females. By performing logarithmic transformations, the linear relationships could be represented by the equation $\mathrm{W}=2.95 T L-11.66\left(\mathrm{R}^{2}=0.86\right)$ for males and $\mathrm{W}$ $=2.87 T L-11.18\left(\mathrm{R}^{2}=0.92\right)$ for females. Males showed isometric growth $(\mathrm{t}=0.65, \mathrm{p}>0.05)$, whereas females showed negative allometric growth $(t=7.96, p<0.001)$. Furthermore, significant differences were detected between males and females for the W/TL relationship (elevation: $\mathrm{t}=17.80, \mathrm{p}<$ 0.001 ), indicating a sexual dimorphism in this case.

A temporal analysis of the allometric condition factor revealed that monthly means varied in a similar way for both sexes over the study period, and showed positive correlation with temperature (male:

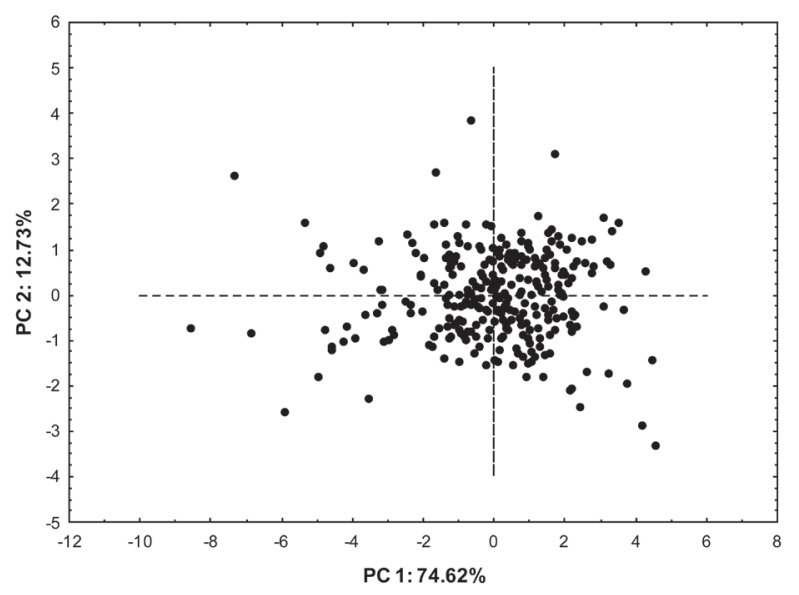

Figure 2. Projection scores of first and second principal component (PC1 and PC2), generated with PCA analysis using morphometric data of males of Macrobrachium amazonicum.

$\mathrm{r}=0.563, \mathrm{p}=0.045$; female: $\mathrm{r}=0.562, \mathrm{p}=0.046)$ (Fig. 3A) and rainfall regime (male: $0.698, \mathrm{p}=$ 0.008; female: 0.467, p = 0.09) (Fig. 3B). Increasing values for the degree of fattening occurred from November 2008 to April 2009, during which increasing rainfall and higher temperatures were also recorded. On the other hand, from May to October water temperature were lower and both the condition factor and rainfall dropped (Tab. 1; Figs. 3A, B). 

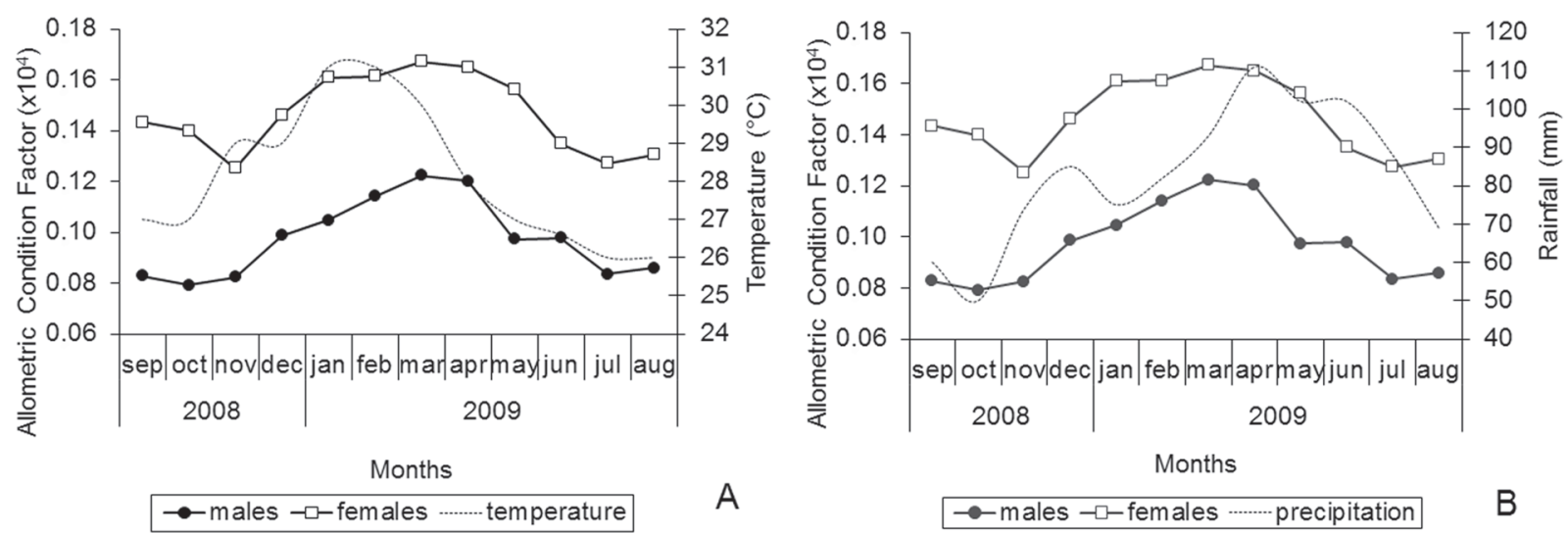

Figure 3. Water temperature (A), rainfall (B) and temporal variation in the condition factor of males and females of Macrobrachium amazonicum.

The values obtained for the relative condition factor $\left(\mathrm{K}_{\mathrm{r}}\right)$ of $M$. amazonicum females were significantly greater than the expected value $(=1)$ between December 2008 and May 2009 ( $p<0.05)$; on the other hand, values were significantly lower than the expected in November 2008 and from June to August 2009 ( $p<0.05$ ); finally, in September and October 2008, there was no statistical difference between the observed and expected $\mathrm{K}_{\mathrm{r}}$ values ( $\mathrm{p}$ > 0.05) (Fig. 4).

For males, obtained $\mathrm{K}_{\mathrm{r}}$ values were statistically greater than the expected value $(=1)$ from February to April 2009 and lower from September to November 2008 and from July to August 2009 ( $\mathrm{p}<0.05)$; in December 2008, January, May and June 2009 the observed $K_{r}$ values for males did not statistically differ from the expected ( $\mathrm{p}$ $>0.05$ ). However, it is possible that the results of the Student's t test for December 2008 ( $\mathrm{n}=$ 10) and January $2009(\mathrm{n}=9)$ were influenced by the small sample size and should be viewed with caution (Fig. 4).

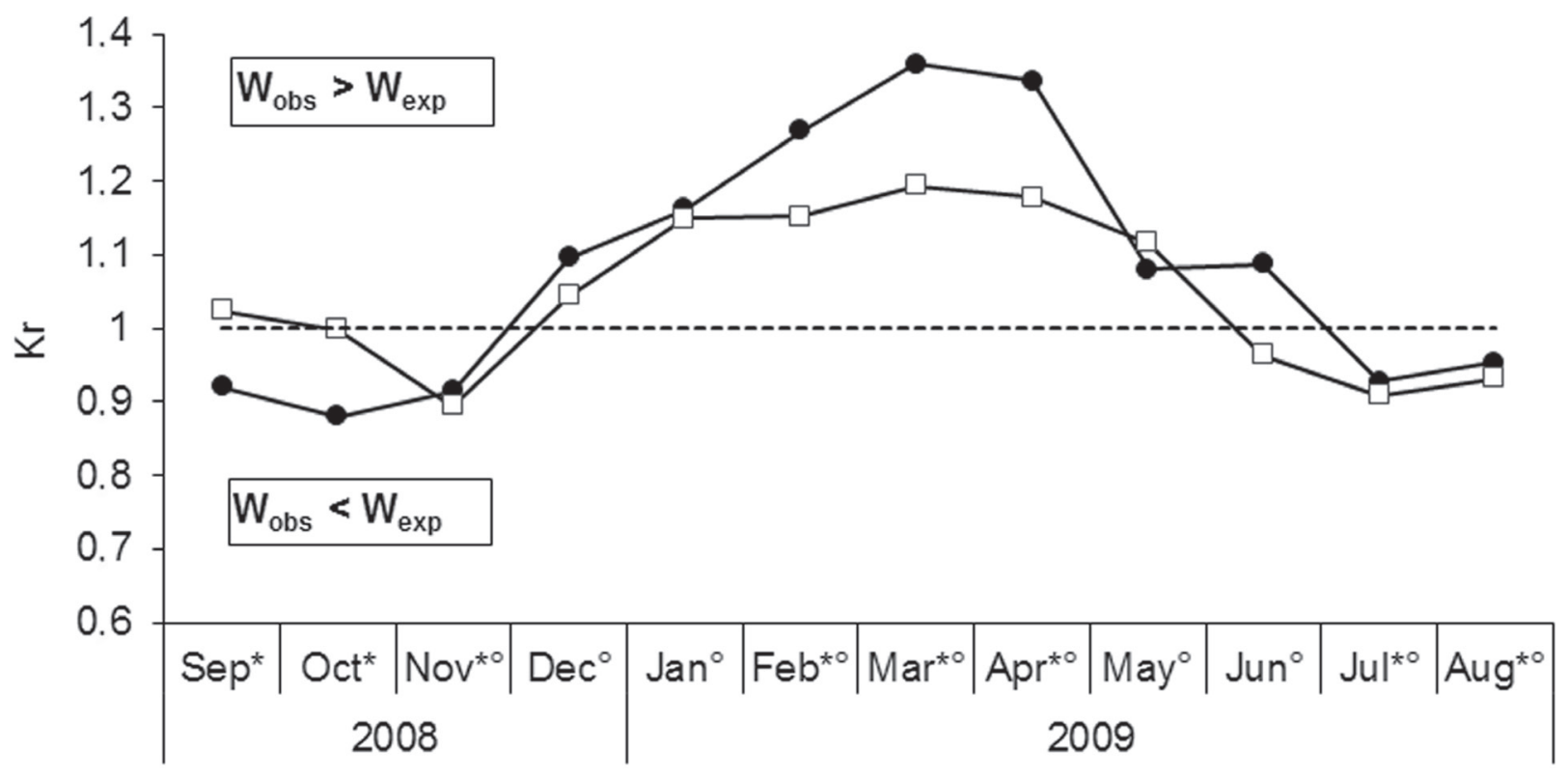

Months

\section{males $\neg \square$-females}

Figure 4. Monthly variation of the relative condition factor $\left(\mathrm{K}_{\mathrm{r}}\right)$ of males and females of Macrobrachium amazonicum. (W ${ }_{\text {obs }}$ ) weight observed; $\left(\mathrm{W}_{\text {exp }}\right.$ ) expected weight; $\left({ }^{*}\right)$ significant difference in males; $\left(^{\circ}\right)$ significant difference in females. 
In the present study no direct correlation between the condition factor and the frequency of ovigerous females was observed $(\mathrm{r}=0.159 ; \mathrm{p}=$ 0.602 ), as these were collected in small percentages throughout the sampling period (except November 2008 and July and August 2009), regardless of variations in the monthly values of the condition factor of females (Fig. 5). Nevertheless, there was a marked decrease in the values of the condition factor from April 2009 onwards, which coincides with a marked increase in the size and weight of individuals, notably in June 2009 (Fig. 6A, B).

\section{DisCUSSION}

Most available information on Macrobrachium amazonicum populations that inhabit rivers (lotic environment) show an overall sex ratio that did not deviate strongly from 1: 1 (Odinetz Collart, 1988;

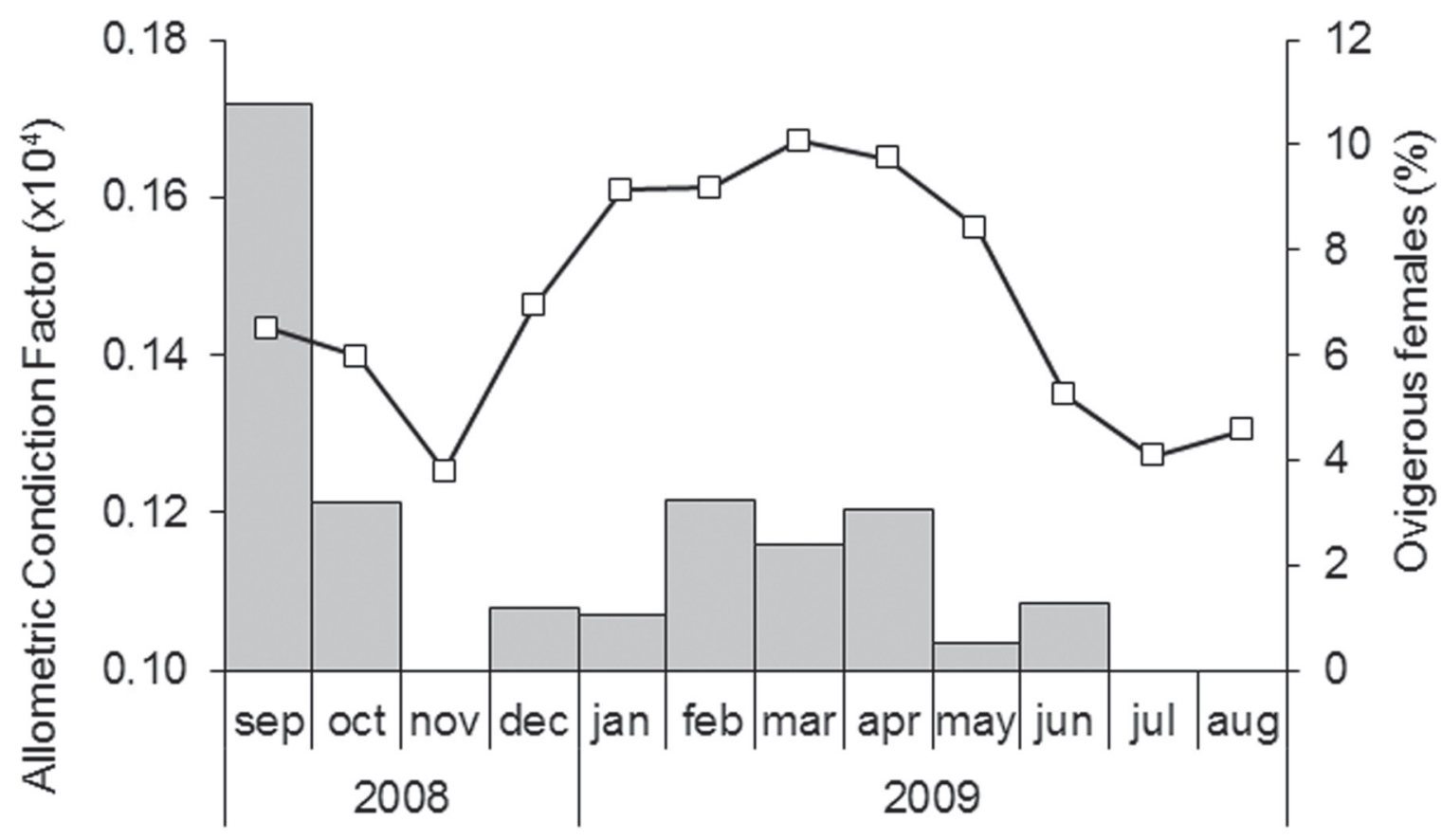

Months

\section{$\square$ ovigerous females $\quad-\square-k$ value of females}

Figure 5. Monthly variation of the condition factor of females and the percentage of ovigerous females of Macrobrachium amazonicum.
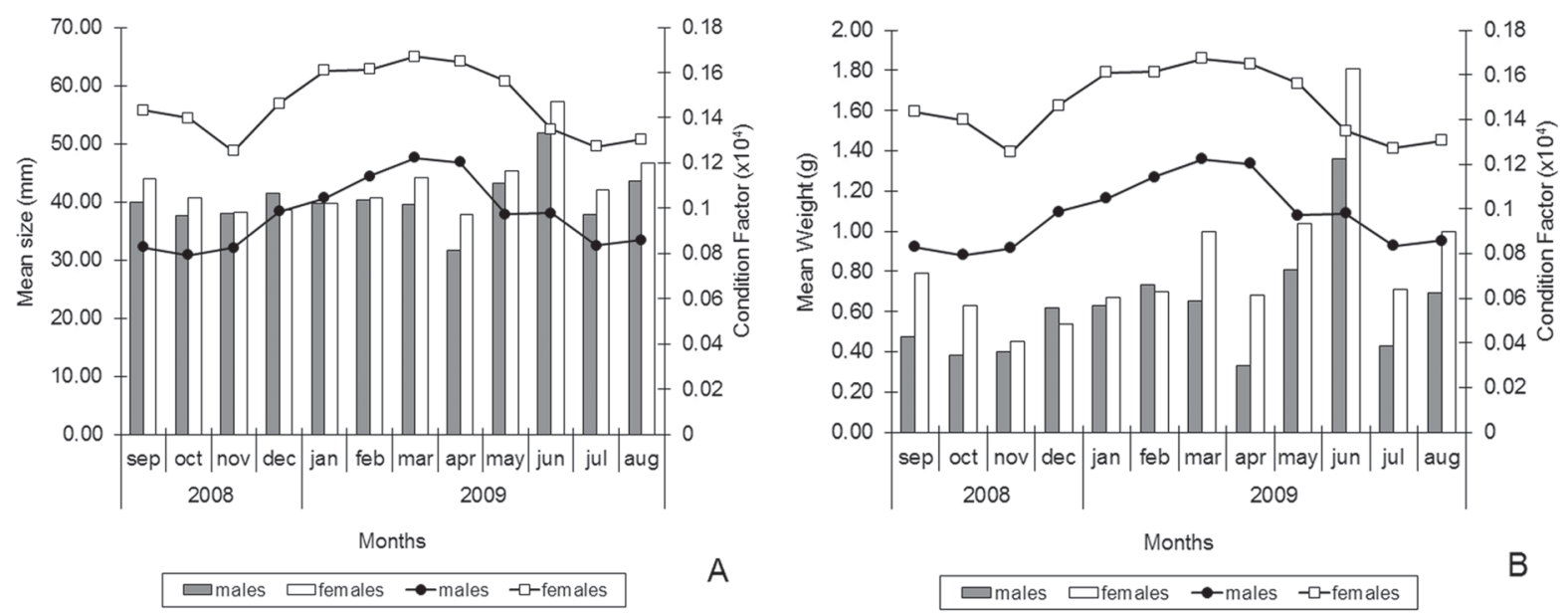

A

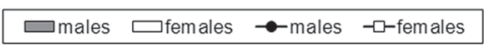

Figure 6. Mean size (A), mean weight (B) and temporal variation in the condition factor of males and females of Macrobrachium amazonicum. 
Flexa et al., 2005; Santos et al., 2006; Sampaio et al., 2007; Silva et al., 2007; Freire et al., 2012), whereas strongly female biased sex ratio frequently occur in lake or floodplain populations, including Pedra do Cavalo Reservoir (Odinetz Collart, 1988, 1991; Silva et al., 2002; Pantaleão et al., 2012; present study). According to Odinetz Collart $(1988,1991)$ this last pattern is typically found in populations that inhabit lentic environment.

Many factors can influence sex ratio of adult crustaceans, such as migration, longevity, different growth rates and mortality between sexes (Wenner, 1972). Nevertheless, Hayd and Anger (2013) mentioned the need for further studies on the relationships between variations in sex ratio, mating systems, ecological conditions and phylogenetic divergence to allow safe conclusions about the female biased sex ratio reported from natural populations of $M$. amazonicum.

With respect to body size, $M$. amazonicum from the coast, the Amazon, and the TocantinsAraguaia River Basins attain larger sizes than any other populations from lotic or lentic environments (Pantaleão et al., 2012). Furthermore, in reservoirs, individuals tend to be smaller, achieve early sexual maturity and the females grow larger than males (Odinetz Collart, 1988, 1991; Odinetz Collart and Moreira, 1993), in comparison with riverine populations (see Table 5 in Pantaleão et al., 2012 for review). Therefore, the results found in this study are consistent with the patterns observed in populations of $M$. amazonicum living in lentic environments.

Distinct male morphotypes described by Moraes-Riodades and Valenti (2004) for the species have been recorded only for lotic environments (Santos et al., 2006; Silva et al. 2009; Pantaleão et al., 2014) and culture ponds (Moraes-Riodades and Valenti, 2004; Papa et al., 2004; MoraesValenti and Valenti, 2007; Moraes-Valenti et al., 2010). Nevertheless, our results corroborated those found by Pantaleão et al. (2012) that only found translucent claw morphotype in a population from Ibitinga Reservoir, which is a lentic environment, similar to Pedra do Cavalo Reservoir.

According to Pantaleão et al. (2012), $M$. amazonicum from lentic environment fits best in the "pure search" mating system (sensu Correa and Thiel, 2003), in which small size is advantageous for males, and they do not need to develop large chelipeds (i.e. male morphotypes). The reproductive success of searching males depends on their ability to find and fertilize as many receptive females as possible without complex pre-copulatory behaviors (Correa and Thiel, 2003). In this context, femalebiased sex ratio (as observed herein, and discussed above) may also be advantageous for the pure search mating system, in which males could mate with different females increasing the reproductive output in population, as suggested by Leme and NegreirosFransozo (1998) for the crab Aratus pisonii ( $\mathrm{H}$. Milne Edwards, 1837).

According Maciel and Valenti (2009), it is possible that populations in reservoirs suffer from degenerative genetic inbreeding, which could result in smaller individuals. Furthermore, given that carnivorous fishes are quite abundant in Brazilian artificial reservoirs (Odinetz Collart, 1988), it is also possible that predation pressure (particularly on larger prawns), allied with the amount and quality of the food available in the environment, result in populations with smaller individuals (Pantaleão $e t$ al., 2012, 2014). Notably in the Pedra do Cavalo Reservoir there are well-established populations of Traíra (Hoplias sp.) (S.B.A. Fonteles, pers. comm.), Tucunaré (Cichla pinima Kullander \& Ferreira, 2006) and Oscar [Astronotus ocellatus (Agassiz, in Spix \& Agassiz, 1831)] (Reis and Santos, 2014), which are voracious fish predator species.

In the case of the $M$. amazonicum population from Pedra do Cavalo Reservoir, which is economically exploited by the riverine communities of Cabaceiras do Paraguaçu and surrounding areas, it is possible that fishing pressure is also contributing to a decrease in the average size of individuals as reported to other crustaceans (Albertoni et al., 2003; Amaral and Jablonski, 2005).

The slopes (b) observed in biometric regressions (Wx TL) of males $(b=2.96)$ and females $(b=2.87)$, though close to each other, determined distinct growth patterns in males (isometry) and females (negative allometry). Nevertheless, several authors have found negative allometry for this ratio for both sexes in coastal populations (Flexa et al., 2005; 
Silva et al., 2007; Freire et al., 2012). Therefore, it is possible that the type of environment (lotic or lentic) may also influence the relative growth pattern of M. amazonicum. According to Hartnoll (1982), the pattern of weight gain is ontogenetically determined, and may vary between males and females of the same species or even among different populations.

The most common pattern for M. amazonicum seems to be greater investment of energy in somatic growth than in weight gain. Relative growth studies conducted by Lobão et al. (1996) and Silva et al. (2002) determined that, in M. amazonicum, the abdomen represents between $51-56 \%$ of the total length of an individual. Such a feature adds commercial value to this prawn, since the abdomen is the most coveted part for human consumption (Lobão et al., 1996).

The condition factor of $M$. amazonicum females was on average 1.5 times greater than that of males. The lower " $b$ " value of females resulted in lower values of the denominator of the ratio $\mathrm{W} /(\mathrm{TL})^{\mathrm{b}}$, which generated higher values of the condition factor in this sex, as observed in other decapod crustaceans (Pinheiro and Taddei, 2005; Pinheiro and Fiscarelli, 2009; Lira et al., 2012). Furthermore, the difference between the values of the condition factor of males and females might be related to the increased capacity of females in storing energy/fat to use it during gonadal maturation, as well as the larger size and weight of the ovaries in comparison with testis (Pinheiro and Taddei, 2005; Gomiero et al., 2008; Araújo et al., 2012; Lira et al., 2012).

In addition, although the monthly means of the allometric condition factor obtained for females were about 1.5 times greater than those for males (as discussed above), a general comparison of the $\mathrm{K}_{\mathrm{r}}$ in the most favorable period for the species (i.e. January-April 2009) showed that males achieved better conditions for weight gain than females, even though in both sexes the observed $\mathrm{K}_{\mathrm{r}}$ was greater than 1.0 (Fig. 4).

According to Molion and Bernardo (2002) the rainy season in the eastern part of Northeast Brazil occur from April to July, during the winter in the southern hemisphere. In the municipality of Cabaceiras do Paraguaçu the rainiest period occurred from April to June (above $100 \mathrm{~mm}$ ), although rainfall began to gradually increase from November and reached a peak in April (Tab. 1). During this period (November to April), higher water temperatures $\left(\right.$ mean $\left.=30^{\circ} \mathrm{C}\right)$ were also recorded. On the other hand, from May to October lower water temperatures $\left(\right.$ mean $\left.=26.6^{\circ} \mathrm{C}\right)$ were recorded and the driest period of the year occurred from August to October (Tab. 1).

During the period of the year when water temperature is higher and rainfall though increasing is below $100 \mathrm{~mm}$, the condition factor of $M$. amazonicum tends to be higher. On the other hand, when rainfall levels reached $100 \mathrm{~mm}$ and water temperature dropped, the condition factor tends to be lower (Fig. 3A, B). Furthermore, considering the monthly values of $K_{r}$, it is possible to conclude that in the months when temperatures are higher and precipitation levels are raising, the condition factor of the prawns is above the expected value (Fig. 4). This corroborates the results found for the allometric condition factor and demonstrates the improved nutritional status of individuals in this period, compared to the period when temperature is lower and rainfall is dropping.

According to Pinheiro and Fiscarelli (2009), the condition factor can be influenced by food availability in the environment. Macrobrachium amazonicum is omnivorous, feeding on filamentous algae, diatoms, aquatic insects and organic debris (Maciel and Valenti, 2009). Stomach analysis of specimens collected in dams in Northeast Brazil revealed large amounts of microalgae (Maciel and Valenti, 2009).

Several studies indicate that phytoplankton productivity and biomass in reservoirs are influenced by many interdependent factors, for instance temperature, precipitation, light and nutrient input (Talling and Rzoska, 1967; Kimmel et al., 1999; Calijuri et al., 2002; Chellappa et al., 2008; Biudes and Camargo, 2008).

In low latitude regions (as Cabaceiras do Paraguaçu, Bahia) there is little variation in temperature compared to high latitudes, where this parameter has greater influence on biomass production (Biudes and Camargo, 2008). On the other hand, rainfall, nutrient availability and 
residence time of water exerts an important influence on seasonal variations in primary productivity in tropical water bodies (Calijuri et al., 2002; Santos and Esteves, 2004; Enrich-Prast and Esteves, 2005).

According to Calijuri et al. (2002), residence time of water in a reservoir is directly related to rainfall, increasing in the dry season and decreasing in the rainy season. At the same time, in the rainiest periods the availability of nutrients (Henry et al., 1998; Calijuri et al., 2002) and levels of suspended solids (Henry et al., 1998; Chellappa et al., 2008) are usually greater. According to Chellappa et al. (2008), the presence of greater amounts of suspended material in the water and their accumulation near the surface decreases the incidence of sunlight, thus decreasing primary production during the rainy season despite the greater input of nutrients.

Thus, longer days when there is more sunlight incidence, less rainfall and higher temperatures could increase primary production in the Pedra do Cavalo Reservoir and hence food availability for prawns, leading to greater accumulation of energy (i.e. condition factor), specially from November to April. However, studies on the hydrological cycle and primary productivity of the Pedra do Cavalo Reservoir are needed to provide data that can be used to verify the influence of these aspects on the nutritional status of $M$. amazonicum.

Several authors have associated monthly or seasonal variations of the condition factor with the cycles of reproductive activity of fish and crustaceans; in general, lower condition factors are associated with investment of the accumulated reserves for reproduction (e.g. spawning and gonadal reorganization) (Pinheiro and Taddei, 2005; Azevedo and Castro, 2008; Pinheiro and Fiscarelli, 2009; Gomiero et al., 2010). However, ovigerous females of $M$. amazonicum from Pedra do Cavalo Reservoir were not sampled in November 2008, July and August 2009 when the lowest values of the condition factor were recorded (Fig. 5).

In addition to reproductive factors, a decrease in the monthly means of the condition factor may be related to energy investment for somatic growth. Pinheiro and Taddei (2005) attributed a reduction in the values of the condition factor of
Dilocarcinus pagei Stimpson, 1861 males to the molt cycle. In the case of males and females of M. amazonicum, after a period of intense energy accumulation (December 2008 to March 2009), there was a marked decrease in the values of the condition factor from April 2009 onwards, which coincides with a marked increase in the size and weight of individuals, notably in June 2009 (Fig. 6). Therefore, it is possible that $M$. amazonicum individuals invested their energy accumulated during previous months on somatic growth.

The study of weight gain and condition factor patterns through relative growth analyses proved to be an important tool to understand the biology of $M$. amazonicum, especially considering the wide geographical distribution and intraspecific variations that occur in different populations of this species. Furthermore, the results presented here provide important information about the "well-being" of M. amazonicum in its environment. Combined with future studies of reproductive biology and population structure, the information provided here could be important for the sustainable use of this important fishery resource for the community of Recôncavo da Bahia and others where this species is also exploited.

\section{ACKNOWLEDGMENTS}

The authors express their sincere gratitude to Centro de Ciências Agrárias, Ambientais e Biológicas Universidade Federal do Recôncavo da Bahia for providing all laboratory facilities; to PROPAAE/ UFRB (Pró-Reitoria de Políticas Afirmativas e Assuntos Estudantis - UFRB) for providing a research grant to one of us (JLS); to Barbara Ferreira Guimarães, Welder Feitosa Souza and Jordana Batista Santana for their help during laboratory activities; and to Mr. Gilson, local fisherman, for his help in sampling the specimens.

\section{REFERENCES}

Albertoni, E.F.; Palma-Silva, C. and Esteves, F.A. 2003. Crescimento e fator de condição na fase juvenil de Farfantepenaeus brasiliensis (Latreille) e F. paulensis (PérezFarfante) (Crustacea, Decapoda, Penaeidae) em uma lagoa costeira tropical do Rio de Janeiro, Brasil. Revista Brasileira de Zoologia, 20(3): 409-418.

Amaral, A.C.Z. and Jablonski, S. 2005. Conservação da biodiversidade marinha e costeira no Brasil. 
Megadiversidade, 1(1): 44-51.

Araújo, M.S.L.C.; Castiglioni, D.S. and Coelho, P.A. 2012. Width-weight relationship and condition factor of Ucides cordatus (Crustacea, Decapoda, Ucididae) at a tropical mangroves of Northeast Brazil. Iheringia, Série Zoologia, 102(3): 277-284.

Araújo, M.S.L.C. and Lira, J.J.P.R. 2012. Condition factor and carapace width versus wet weight relationship in the swimming crab Callinectes danae Smith 1869 (Decapoda, Portunidae) at the Santa Cruz Channel, Pernambuco State, Brazil. Nauplius, 20(1): 41-50.

Azevedo, J.W.J. and Castro, A.C.L. 2008. Relação peso-comprimento e fator de condiçáo do Uritinga, Hexanematichthys proops, (Valenciennes, 1840) (Siluriformes, Ariidae), capturado no litoral ocidental do Maranhão. Boletim do Laboratório de Hidrobiologia, 21(1): 75-82.

Barbieri, G.; Vermulm Júnior H.; Giamas, M.T.; Teixeira Filho, A.R. and Campos, E.C. 2000. Biologia populacional da Tilápia, Oreochromis niloticus, da represa de Guarapiranga, São Paulo - I. Estrutura da população, idade e crescimento. Boletim do Instituto de Pesca, 26(1): 1-7.

Biudes, J.F.V. and Camargo, A.F.M. 2008. Estudos dos fatores limitantes à produção primária por macrófitas aquáticas no Brasil. Oecologia Brasiliensis, 12(1): 7-19.

Bolger, T. and Connolly, P.L. 1989. The selection of suitable indices for the measurement and analysis of fish condition. Journal of Fish Biology, 34(2): 171-182.

Braga, F.M.S. 1986. Estudo entre o fator de condição e relação peso-comprimento para alguns peixes marinhos. Revista Brasileira de Biologia, 46(2): 339-346.

Bragagnoli, G. and Grotta, M. 1995. Reprodução do camarão de água doce Macrobrachium amazonicum do açude Epitácio Pessoa, Boqueirão (PB), Brasil. Parte 1: ciclo sexual. Revista Nordestina de Biologia, 10(2): 141-154.

Branco, J.O.; Lunardon, M.J.; Avila, M.G. and Miguez, C.F.M. 1992. Interação entre fator de condição e índice gonadossomático como indicadores do período de desova em Callinectes danae Smith (Crustacea, Portunidae,) da Lagoa da Conceição, Florianópolis, Santa Catarina, Brasil. Revista Brasileira de Zoologia, 9(3/4): 175-180.

Branco, J.O. and Lunardon-Branco, M.J. 1993. Aspectos da biologia de Callinectes ornatus Ordway, 1563 (Decapoda, Portunidae) da regiāo de Matinhos, Paraná, Brasil. Arquivos de Biologia e Tecnologia, 36(3): 489-496.

Branco, J.O. and Thives, A. 1991. Relaçáo peso-comprimento, fator de condição e tamanho de primeira maturação de Callinectes danae Smith, 1896 (Crustacea, Portunidae) no Manguezal do Itacorubi, SC, Brasil. Arquivos de Biologia e Tecnologia, 34(3/4): 415-424.

Calijuri, M.C.; dos Santos, A.C.A. and Jati, S. 2002. Temporal changes in the phytoplankton community structure in a tropical and eutrophic reservoir (Barra Bonita, SP - Brazil). Journal of Plankton Research, 24(7): 617-634.

Chellappa, N.T.; Borba, J.M. and Rocha, O. 2008. Phytoplankton community and physical-chemical characteristics of water in the public reservoir of Cruzeta, RN, Brazil. Brazilian Journal of Biology, 68(3): 477-494.

Coelho, P.A. and Ramos-Porto, M. 1985. Camaróes de água doce do Brasil: distribuiçẫo geográfica. Revista Brasileira de Zoologia, 2(6): 405-410.

Correa, C. and Thiel, M. 2003. Mating system in caridean shrimp (Decapoda: Caridea) and their evolutionary consequences for sexual dimorphism and reproductive biology. Revista Chilena de Historia Natural, 76(2): 187203.

Enrich-Prast, A. and Esteves, F.A. 2005. Flood pulse influence and anthropic impact on the chemical composition and energy content of Oryza glumaepatula in an Amazonian lake. Brazilian Journal of Biology, 65(3): 451-458.

Flexa, C.E.; Silva, K.C.A. and Cintra, I.H.A. 2005. Morfometria do camarão-canela, Macrobrachium amazonicum (Heller, 1862), no município de Cametá Pará. Boletim Técnico-Científico do CEPNOR, 5(1): 41-54.

Freire, J.L.; Marques, C.B. and Silva, B.B. 2012. Population structure and reproductive biology of Macrobrachium amazonicum (Heller, 1862) (Decapoda: Palaeomonidae) in an estuary in northeast Pará, Brazil. Brazilian Journal of Aquatic Science and Technology, 16(2): 65-76.

Genz, F. 2006. Avaliação dos efeitos da barragem Pedra do Cavalo sobre a circulação estuarina do rio Paraguaçu e Baía de Iguape. Universidade Federal da Bahia - UFBA, Salvador, Brazil, Ph.D. Thesis. 245p. [Unpublished].

Gomiero, L.M. and Braga, F.M.S. 2003. Relação pesocomprimento e fator de condição para Cichla cf. ocellaris e Cichla monoculus (Perciformes, Cichlidae) no reservatório de Volta Grande, Rio Grande - MG/SP. Acta Scientiarum. Biological Sciences, 25(1): 79-86.

Gomiero, L.M. and Braga, F.M.S. 2005. The condition factor of fishes from two river basins in São Paulo state, Southeast of Brazil. Acta Scientiarum. Biological Sciences, 27(1): 63-71.

Gomiero, L.M. and Braga, F.M.S. 2006. Relação pesocomprimento e fator de condição de Brycon opalinus (Pisces, Characiformes) no Parque Estadual da Serra do Mar - Núcleo Santa Virgínia, Mata Atlântica, estado de São Paulo, Brasil. Acta Scientiarum. Biological Sciences, 28(2): 135-141.

Gomiero, L.M.; Vilares Junior, G.A. and Braga, F.M.S. 2010. Relaçáo peso-comprimento e fator de condição de Oligosarcus hepsetus (Cuvier, 1829) no Parque Estadual da Serra do Mar - Núcleo Santa Virgínia, Mata Attântica, estado de São Paulo, Brasil. Biota Neotropica, 10(1): 101-105.

Gomiero, L.M.; Vilares Junior, G.A. and Naous, F. 2008. Relaçáo peso-comprimento e fator de condiçáo de Cichla kelberi (Perciformes, Cichlidae) introduzidos em um lago artificial no sudeste brasileiro. Acta Scientiarum. Biological Sciences, 30(2): 173-178.

Hammer, O.; Harper, D.A.T. and Ryan, P.D. 2001. Past: Paleontological Statistics Software Package for Education and Data Analysis. Paleontological Electronica, 4(1): 9p. Available at: http://palaeo-electronica.org/2001_1/past/ past.pdf. Accessed on 16 December 2013.

Hartnoll, R.G. 1982. Growth. p. 111-196. In: L.G. Abele (ed), The Biology of Crustacea. Embryology, Morphology and Genetics, Vol. 2. New York, Academic Press.

Hayd, L. and Anger, K. 2013. Reproductive and morphometric traits of Macrobrachium amazonicum (Decapoda: Palaemonidae) from the Pantanal, Brazil, suggests initial speciation. Revista de Biología Tropical, 61(1): 39-57.

Heller, C. 1862. Beiträge zur näheren Kenntnis der Macrouren. Sitzungsberichte der mathematisch-naturwissenschaftlichen Classe der Kaiserlichen Akademie der Wissenschaften in Wien, 
45(1): 389-426.

Henry, R.; Nunes, M.A.; Mitsuka, P.M.; de Lima, N. and Casanova, S.M.C. 1998. Variação espacial e temporal da produtividade primária pelo fitoplâncton na represa de Jurumirim (rio Paranapanema, SP). Revista Brasileira de Biologia, 58(4): 571-590.

Isaac-Nahum, V.J. and Vazzoler, A.E.A.M. 1983. Biologia reprodutiva de Mycropogonias furnieri (Desmarest, 1823) (Teleostei, Scianidae): fator de condição como indicador do período de desova. Boletim do Instituto Oceanográfico, 32(1): 63-69.

Kimmel, B.L.; Lind, O.T. and Paulson, L.J. 1999. Reservoir primary production. p. 133-194. In: K.W. Thornton; B.L. Kimmel and F.E. Payne (eds), Reservoir limnology: ecological perspectives. New York, J. Wiley and Sons.

Kullander, S.O. and Ferreira, E.J.G. 2006. A review of the South American cichlid genus Cichla, with descriptions of nine new species (Teleostei: Cichlidae). Ichthyological Exploration of Freshwaters, 17(4): 289-398.

Le Cren, E.D. 1951. The length-weight relationship and seasonal cycle in gonad weight and condition factor in the perch (Perca fluviatilis). Journal of Animal Ecology, 20(2): 201-219.

Leme, M.H.A. and Negreiros-Fransozo, M.L. 1998. Reproductive patterns of Aratus pisonii (Decapoda: Grapsidae) from an estuarine area of Sao Paulo Northern Coast, Brazil. Revista de Biología Tropical, 46(3): 673-678.

Lira, J.J.P.R.; Calado, T.C.S. and Araújo, M.S.L.C. 2012. Condition factor of Goniopsis cruentata (Crustacea, Brachyura, Grapsidae) from Mundaú/Manguaba estuarine complex, Alagoas, Brazil. Iheringia, Série Zoologia, 102(3): 285-291.

Lima-Junior, S.E and Goitein, R. 2006. Fator de condição e ciclo gonadal de fêmeas de Pimelodus maculatus (Osteichthyes, Pimelodidae) no rio Piracicaba (SP, Brasil). Boletim do Instituto de Pesca, 32(1): 87-94.

Lobão, V.L.; Roverso, E.A.; Lace, M. and Hortencio, E. 1996. Ciclo de muda e crescimento em Macrobrachium amazonicum Heller, 1862 e Macrobrachium rosenbergii De Man (Decapoda, Palaemonidae). Boletim do Instituto de Pesca, 23(único): 31-45.

Lucena-Frédou, F.; Rosa Filho, J.S.; Silva, M.C.N. and Azevedo, E. 2010. Population dynamics of the river prawn Macrobrachium amazonicum (Heller, 1862) (Decapoda, Palaemonidae) on Combu Island (Amazon Estuary). Crustaceana, 83(3): 277-290.

Maciel, C.R. and Valenti, W.C. 2009. Biology, fisheries, and aquaculture of the Amazon River prawn Macrobrachium amazonicum: A review. Nauplius, 17(2): 61-79.

Melo, G.A.S. 2003. Famílias Atyidae, Palaemonidae e Sergestidae. p. 289-415. In: G.A.S. Melo (ed), Manual de identificação dos Crustacea Decapoda de água doce do Brasil. São Paulo, Ediçóes Loyola.

Milne-Edwards, H. 1837. Histoire naturelle des Crustacés, comprenant l'anatomie, la physiologie et la classification de ces animaux. Paris, Librairie de Roret, 532p.

Molion, L.C.B. and Bernardo, S.O. 2002. Uma Revisão da Dinâmica das Chuvas no Nordeste Brasileiro. Revista Brasileira de Meteorologia, 17(1): 1-10.

Moraes-Riodades, P.M.C and Valenti, W.C. 2002. Crescimento relativo do camarão canela Macrobrachium amazonicum (Heller) (Crustacea, Decapoda, Palaemonidae) em viveiros.
Revista Brasileira de Zoologia, 19(4): 1169-1176.

Moraes-Riodades, P.M.C and Valenti, W.C. 2004. Morphotypes in male Amazon River prawns, Macrobrachium amazonicum. Aquaculture, 236(1-4): 297-307.

Moraes-Valenti, P.M.; Morais, P.A.; Preto, B.L. and Valenti, W.C. 2010. Effect of density on population development in the Amazon River prawn Macrobrachium amazonicum. Aquatic Biology, 9(3): 291-301.

Moraes-Valenti, P.M. and Valenti, W.C. 2007. Effect of intensification on grow out of the Amazon River prawn, Macrobrachium amazonicum. Journal of the World Aquaculture Society, 38(4): 516-525.

Odinezt Collart, O. 1988. Aspectos ecológicos do camarão Macrobrachium amazonicum (Heler, 1862) no Baixo Tocantins (PA-Brasil). Memória Sociedad de Ciencias Naturales La Salle, 48(Supl.): 341-353.

Odinetz Collart, O. 1991. Tucuruí dam and the populations of the prawn Macrobrachium amazonicum in the Lower Tocantins (PA-Brasil): a four years study. Archive für Hidrobiologie, 122(2): 213-228.

Odinetz Collart, O. and Moreira, L.C. 1993. Migração vertical das larvas de Macrobrachium amazonicum num lago de várzea na Amazônia Central, Ilha do Careiro, Brasil. Amazoniana, 3(4): 385-389.

Papa, L.P.; Vicentini, I.B.F.; Ribeiro, K.; Vicentini, C.A. and Pezzato, L.E. 2004. Diferenciaçáo morfotípica de machos do camarão de água doce Macrobrachium amazonicum a partir da análise do hepatopâncreas e do sistema reprodutor. Acta Scientiarum. Animal Sciences, 26(4): 463-467.

Pantaleão, J.A.F.; Hirose, G.L. and Costa, R.C. 2012. Relative growth, morphological maturity, and size of Macrobrachium amazonicum (Heler, 1862) (Crustacea, Decapoda, Palaemonidae) in a population with an entirely freshwater life cycle. Invertebrate Reproduction and Development, 56(3): 180-190.

Pantaleão, J.A.F.; Hirose, G.L. and Costa, R.C. 2014. Ocurrence of male morphotypes of Macrobrachium amazonicum (Caridea, Palaemonidae) in a population with an entirely freshwater life cycle. Brazilian Journal of Biology, 74(3): 223-232.

Patil, K.M. and Patil, M.U. 2012. Length-weight relationship and condition factor of freshwater crab Barytelphusa gurini, (Decapoda, Brachyura). Journal of Experimental Sciences, 3(5): 13-15.

Pileggi, L.G. and Mantelatto, F.L. 2010. Molecular phylogeny of the freshwater prawn genus Macrobrachium (Decapoda, Palaemonidae), with emphasis on the relationships among selected American species. Invertebrate Systematics, 24(2): 194-208.

Pinheiro, M.A.A. and Fiscarelli, A.G. 2009. Length-weight relationship and condition factor of the Mangrove Crab Ucides cordatus (Linnaeus, 1763) (Crustacea, Brachyura, Ucididae). Brazilian Archives of Biology and Technology, 52(2): 397-406.

Pinheiro, M.A.A. and Taddei, F. 2005. Relação peso/largura da carapaça e fator de condição em Dilocarcinus pagei Stimpson (Crustacea, Trichodactylidae), em Sáo José do Rio Preto, São Paulo, Brasil. Revista Brasileira de Zoologia, 22(4): 825-829.

Reis, L.R.G. and Santos, A.C.A. 2014. Dieta de duas espécies de peixes da família Cichlidae (Astronotus ocellatus e Cichla 
pinima) introduzidos no rio Paraguaçu, Bahia. Biotemas, 27(4): 83-91.

Sampaio, C.M.S.; Silva, R.R.; Santos, J.A. and Sales, S.P. 2007. Reproductive cycle of Macrobrachium amazonicum females (Crustacea, Palaemonidae). Brazilian Journal of Biology, 67(3): 551-559.

Santos, A.; Hayd, L. and Anger, K. 2013. A new species of Macrobrachium Spence Bate, 1868 (Decapoda, Palaemonidae), M. pantanalense, from the Pantanal, Brazil. Zootaxa, 3700(4): 534-546.

Santos, A.M. and Esteves, F.A. 2004. Influence of water level fluctuation on the mortality and aboveground biomass of the aquatic macrophyte Eleocharis interstincta (VAHL) Roemer et Schultz. Brazilian Archives of Biology and Technology, 47(2): 281-290.

Santos, E.P. 1978. Dinâmica de populaçôes aplicada à pesca e aqüicultura. São Paulo, HUCITEC/EDUSP, 129 p.

Santos, J.A.; Sampaio, C.M.S. and Soares Filho, A.A.S. 2006. Male population structure of the Amazon River prawn (Macrobrachium amazonicum) in a natural environment. Nauplius, 14(2): 55-63.

Sá-Oliveira, J.C.; Chellappa, S. and Vasconcelos, H.C.G. 2011. Estrutura populacional, relação peso-comprimento e fator de condiçáa de Hoplosternum littorale, Hancock, 1828 (Siluriformes: Callichthyidae) da Área de Proteção Ambiental do rio Curiaú, Macapá-AP. Biota Amazônia, 1(1): 38-41.

Silva, G.M.F.; Ferreira, M.A.P.; von Ledebur, E.I.C.F. and Rocha, R.M. 2009. Gonadal structure analysis of Macrobrachium amazonicum (Heller, 1862) from a wild population: a new insight into the morphotype characterization. Aquaculture Research, 40(7): 798-803.

Silva, K.C.A.; Souza, R.A.L. and Cintra, I.H.A. 2002. Camarão-cascudo Macrobrachium amazonicum (Heller, 1862) (Crustacea, Decapoda, Palaemonidae) no município de Vigia-Pará-Brasil. Boletim Técnico Científico CEPNOR, 2(1): 41-73.
Silva, M.C.N.; Frédou, F.L. and Rosa Filho, J.S. 2007. Estudo do crescimento do camarão Macrobrachium amazonicum (Heller, 1862) da Ilha do Combú, Belém, Estado do Pará. Amazônia Ciência \& Desenvolvimento, 2(4): 85-104.

Silva, R.R.; Sampaio, C.M.S. and Santos, J.A. 2004. Fecundity and fertility of Macrobrachium amazonicum (Crustacea, Palaemonidae). Brazilian Journal of Biology, 64(3A): 489-500.

Spix, J.B. and Agassiz, L. 1831. Selecta genera et species piscium quos in itinere per Brasiliam annos MDCCCXVIIMDCCCXX jussu et auspiciis Maximiliani Josephi I.... colleget et pingendso curavit Dr J. B. de Spix.... Monachii. Part 2: 83-138, Pls. 49-101.

Stimpson, W.N. 1861. Notes on certain decapod Crustacea. Proceedings of the Academy of Natural Sciences in Philadelphia, 13(1): 372-375.

Talling, J.F. and Rzoska, J. 1967. The development of plankton in relation to hydrological regime in the Blue Nile. Journal of Ecology, 55(3): 637-662.

Tavares-Dias, M.; Marcon, J.L.; Lemos, J.R.G.; Fim, J.D.I.; Affonso, E.G. and Ono, E.A. 2008. Îndices de condição corporal em juvenis de Brycon amazonicus (Spix \& Agassiz, 1829) e Colossoma macropomum (Cuvier, 1818) na Amazônia. Boletim do Instituto de Pesca, 34(2): 197-204.

Vazzoler, A.E.A.M. 1981. Manual de métodos para estudos biológicos de populaçôes de peixes: reprodução e crescimento. Brasília, Programa Nacional de Zoologia (CNPq), 106p.

Vergamini, F.G.; Pileggi, L.G. and Mantelatto, F.L. 2011. Genetic variability of the Amazon River prawn Macrobrachium amazonicum (Decapoda, Caridea, Palaemonidae). Smithsonian Contributions to Zoology, 80(1): 67-83.

Wenner, A.M. 1972. Sex ratio as a function of size in marine Crustacea. The American Naturalist, 106(949): 321-350.

Zar, J.H. 1996. Biostatistical Analysis. New Jersey, Prentice Hall, 662p.

Submitted 28 January 2015

Accepted 24 July 2015 
